\title{
Responses of Nurses and Other Healthcare Workers to Sexual Harassment in the Workplace
}

\author{
Claire Burke Draucker
}

\begin{abstract}
Sexual harassment against healthcare workers is an international problem, but little is known about how recipients of sexual harassment respond to this type of workplace violence. An integrative review was conducted that summarized the findings of 15 studies from around the world that revealed how healthcare workers respond to sexual harassment. The review indicated that recipients of sexual harassment experience a wide variety of aversive feelings, including fear, anger, and shock. Some also experience negative psychological and physical harms and negative employment-related consequences. In conclusion, more studies using increasingly sophisticated designs are required to develop an explanatory model that explicates complex relationships among characteristics of the harassment, institutional responses, and responses of the recipients over time.
\end{abstract}

Key Words: Sexual harassment, sexual violence, inappropriate sexual behaviors, healthcare workers, healthcare professionals, nurses, physicians, coping, negative effects, physical health effects, mental health effects, employment/employees, workplace

This is the author's manuscript of the work published in final form as:

Draucker, C.B. (2019). Responses of Nurses and Other Healthcare Workers to Sexual Harassment in the Workplace. Online Journal of Issues in Nursing, 24(1), 9-9.

https://doi.org/10.3912/OJIN.Vol24No01Man03 


\section{Responses of Nurses and Other Healthcare Workers to Sexual Harassment in the Workplace}

Sexual harassment against nurses and other healthcare workers is a significant problem worldwide. Sexual harassment is defined by the World Health Organization and several international health organizations as "unwanted conduct that is perceived by the victims as placing conditions of a sexual nature on their employment, or that might, on reasonable grounds, be perceived by the victims as an offence, a humiliation or a threat to their well-being" (di Martino, 2003, p. 2). Sexual harassment has significant health- and employment-related effects on recipients (Pina \& Gannon, 2012). Moreover, those who experience sexual harassment respond to and cope with the harassment in a wide variety of ways (Cortina \& Wasti, 2005).

Although a long-standing problem in the workplace, sexual harassment became a major focus of national and international discourses. This is due largely in part to the \#MeToo Movement, a crusade that garnered worldwide attention when a number of Hollywood actors exposed prominent and powerful leaders in the entertainment industry of sexual harassment and sexual assault (Langone, 2018). The movement was advanced when The New Yorker and The New York Times published a series of articles in which investigative journalists exposed the sexual misconduct of Hollywood producer Harvey Weinstein and others (Langone, 2018). While the \#MeToo Movement exploded globally in 2017 and 2018, the phrase "Me Too" was initially launched over a decade ago by Tarana Burke, a community activist who organized survivors of sexual violence to help other survivors, especially women and girls of color (Langone, 2018; von Gruenigen \& Karlan, 2018).

Sexual harassment is a phenomenon rooted in cultures of injustice, hierarchical structures, and gender inequality and has occurred in all industries, including the healthcare industry, for 
decades (von Gruenigen \& Karlan, 2018). The \#MeToo Movement, however, created renewed focus on the problem of sexual harassment in the healthcare professions. Editorials in the New England Journal of Medicine (Jagsi, 2018) and the American Journal of Nursing (Nelson, 2018) put a spotlight on the problem of sexual harassment in the fields of medicine and nursing.

Sexual harassment in healthcare settings is a worldwide problem (Freischlag \& Faria, 2018). A quantitative review of 136 studies representing 151,347 nurses from 38 countries examined physical and nonphysical violence, bullying, and sexual harassment against nurses (Spector, Zhou, \& Che, 2014). Thirty-three samples were queried about sexual harassment, and the review revealed that the exposure rate for sexual harassment of nurses in these samples was $27.9 \%$. The countries were divided into cultural/geographic regions that were represented in the studies: the Anglo region (e.g., English-speaking countries with cultural similarities, such as Australia, Canada, England, and United States), Europe, Middle East, and Asia. The rate of sexual harassment of nurses was highest in the Anglo region (38.7\%) and lowest in Europe (16.2\%).

Decades of research have revealed that sexual harassment has significant negative consequences for recipients (Pina \& Gannon, 2012). Outcomes of sexual harassment in the workplace are often divided into health- and employment-related effects (Pina \& Gannon, 2012). A meta-analysis of 41 studies that included a total of 70,000 participants revealed that sexual harassment has negative effects on the mental and physical health of recipients and is associated with symptoms of post-traumatic stress (Willness, Steel, \& Lee, 2007). The meta-analysis also revealed that sexual harassment is associated with decreased job satisfaction; organizational commitment (e.g., affective attachment to the organization); organizational withdrawal, including work withdrawal (e.g., avoiding work tasks) and job withdrawal (e.g., intent to leave the organization); and lowered workgroup productivity (Willness, Steel, \& Lee, 2007). 
While the effects of sexual harassment on the well-being of recipients are being examined, the ways in which recipients cope with sexual harassment are less extensively studied. However, Pina and Gannon (2012), who reviewed the literature on victims' responses to sexual harassment, suggested that there are four general types of coping responses: formal reports, informal complaints, social support strategies, and attempts to communicate with the harasser. The review revealed that the coping strategy most commonly reported in the literature was seeking support from friends and co-workers, but only support from friends was shown to be helpful. The reviewers suggested that workers might prefer to rely on their close personal network for support because co-workers might be doubtful or dismissive about the harassment.

Cortina and Wasti (2005) examined sexual harassment coping behavior in four groups: workingclass Hispanic Americans, working-class Anglo Americans, professional Turks, and professional Anglo Americans. The review revealed three common coping patterns: avoidant negotiating, support seeking, and detached. The avoidant negotiating pattern involved high levels of denial and avoidance coupled with attempts to negotiate with the harasser in order to curtail the behavior. The support seeking pattern involved seeking informal support from friends or formal support from management. The detached pattern involved denying the severity of the harassment and doing little to cope with it.

Despite the widespread acknowledgement of sexual harassment as a significant workforce issue in healthcare contexts worldwide, the responses of nurses and other healthcare professionals who are the recipients of the harassment have not been well identified and described in detail. An understanding of the ways in which sexual harassment affects nurses and other healthcare workers who are exposed to it is required to inform prevention and treatment efforts. The purpose of this review was to identify and describe common responses of nurses and other 
healthcare workers to sexual harassment in the workplace. To accomplish this aim, an integrative review was conducted. Integrative reviews produce a summary of available empirical evidence on a particular problem and is the review method of choice when the aim is the integration of research findings derived from studies using diverse methodologies (Whittemore \& Knafl, 2005). In order to capture the findings of a broad-based body of studies that use a variety of approaches, an integrative review was determined to be the most appropriate type of review to address the study purpose.

\section{Review Methods}

The integrative review was conducted using the five-stage process described by Whittemore and Knafl (2005). The five stages include (1) problem identification, (2) literature search, (3) data evaluation, (4) data analysis, and (5) presentation.

\section{Problem Identification}

This stage includes identifying the problem to be addressed and the variables of interest (Whittemore \& Knafl, 2005). The problem to be addressed in this review is the identification and description of common responses of nurses and other healthcare workers to incidents of sexual harassment in the workplace. Behaviors that met the definition of sexual harassment presented above (i.e., di Martino, 2003) but were labeled with other terms (e.g., sexual violence, inappropriate sexual behaviors) were considered to be sexual harassment for the purpose of the review. Any health- or employment-related effects and coping strategies used in response to the sexual harassment were considered recipient responses. Because a wide variety of healthcare workers likely share common responses to sexual harassment, samples could include persons who worked in any healthcare setting (e.g., hospital, clinic, community) and were from any 
healthcare discipline (e.g., nurses, physicians, therapists, chiropractors, careworkers) as well as students or trainees in these disciplines.

\section{Literature Search}

The literature search was limited to empirical studies conducted between 2005 and August 2018. Although the beginning date is somewhat arbitrary, it was chosen because while articles regarding sexual harassment in healthcare started to appear as early as 1981, empirical studies about sexual harassment in healthcare began to appear fairly regularly around 2005.

A combination of search terms related to healthcare workers, including all healthcare disciplines and settings; sexual harassment and related behaviors; and recipient responses (e.g., physical and mental effects, health outcomes, employment outcomes, coping) were used to search three databases: CINAHL, MEDLINE, and PsychINFO. In addition, the strategy of ancestry searching (i.e., searching for relevant citations in articles included in the review) was also used.

The following inclusion criteria were used to identify reports to be included in the review: (a) reported on a primary research study; (b) appeared in a peer-reviewed journal; (c) published between January 2005 and August 2018; (d) sample included healthcare workers of any discipline employed in any type of setting; (e) measured sexual harassment OR obtained narratives of persons who experienced sexual harassment; and (f) identified any type of response to sexual harassment. Reports were excluded if measures or narratives related to sexual harassment could not be disentangled from measures or narratives related to workplace violence more generally. For example, if an article measured sexual harassment as a component of workplace violence but did not provide an index of the association between sexual harassment specifically and a response to the harassment, that article was excluded. 
The three database and ancestry searches yielded a total of 267 reports. The abstracts of these articles were reviewed, and 15 articles were included in the final sample. Most of the discarded articles were excluded because they reported findings related to incidence, risk factors, or other factors (e.g., perpetrators) of sexual harassment toward healthcare workers but did not report findings related to recipients' responses to sexual harassment.

\section{Data Evaluation}

In some reviews, the methodological quality of each report is assessed and a quality score or specific criteria is used as an inclusion criteria. However, the assessment of quality is complex and varies according the research design (Whittemore \& Knafl, 2005). As the purpose of this review was to identify a wide variety of common responses to sexual harassment, a quality evaluation for inclusion/exclusion of reports was not conducted, but methodological limitations of this body of work as a whole are addressed in the discussion.

\section{Data Analysis}

In order to summarize the data, a data display table was developed that lists the reports in the order in which they were published (see Table 1). Data extracted from each report included the citation, the study purpose, the study design, the setting/sample, the variable/measure of sexual harassment, the variable/measure of recipient responses, and findings related to recipient responses to sexual harassment. A summary of the key characteristic of studies in the final sample and the nature of the sexual harassment experienced by the participants are first presented to provide the context for the review findings. The findings of the reports regarding recipient response are then categorized and each category is described.

\section{Table 1. Summary Table of Reports of Studies Investigating Healthcare Workers}

\section{Responses to Sexual Harassment, 2005-2018}




\section{Characteristics of the Reports}

As seen in Table 2, the studies were conducted in 12 different countries; 3 were conducted in Turkey and each of the other studies was conducted in a different country. Thirteen of the studies used a cross-sectional survey design, and 2 used a qualitative approach. The sample sizes of the cross-sectional surveys ranged from 19 (Gleberzon, Statz, \& Pym, 2015) to 1384 (Wilkinson, Gill, Fitzjohn, Palmer \& Mulder, 2006), and the qualitative studies had sample sizes of 10 (MacKusick \& Minick, 2010) and 39 (Nielson et al., 2017). In regards to the composition of the samples, nurses and/or nursing students comprised the samples of 8 of the studies, whereas 3 studies included healthcare workers of several disciplines. Two studies included medical students, 1 included qualified speech language pathologists and audiologists (SLP/As) and SLP/A students, and 1 included faculty from a school of chiropractic medicine.

\section{Nature of the Sexual Harassment}

Sexual harassment was the label used in most of the studies, although terms such as inappropriate sexual behaviors (ISB) (Levin \& Traub, 2006), sexual humor/sexual advances (Wilkinson et al., 2006), and sexual violence (Kvas \& Seljak, 2014) were also used. The rates of sexual harassment varied across studies. Past year rates were fairly consistent, ranging from $11.4 \%$ of a sample of nurses in Slovenia (Kvas \& Seljak, 2014) to $15.9 \%$ of a sample a varied types of healthcare workers in Turkey (Talas, Kockõz, \& Akgüç, 2011). Most rates of lifetime prevalence of sexual harassment for healthcare works, exclusive of students, ranged from $37 \%$ of a sample of nurses in Turkey (Çelik \& Çelik, 2007) to $63.4 \%$ of a sample of nurses in China (Yang, Stone, Petrini, \& Morris, 2018). One study (Demir \& Rodwell, 2012) of nurses in Australia found unusually low prevalence rates for sexual harassment by patients and visitors $(2.0 \%)$ and by co-workers or supervisors $(2.9 \%)$. The rates of lifetime prevalence of sexual 
harassment in student samples ranged widely from $14 \%$ of medical students in New Zealand (Wilkinson et al., 2006) to 67.3\% of doctors-in-training in Turkey (Ulusoy, Swigart, \& Erdemir, 2011).

...participants were asked to identify the source of the sexual harassment and a wide variety of groups were implicated... In most of the studies, participants were asked to identify the source of the sexual harassment and a wide variety of groups were implicated, including patients or clients, patients' or clients' families, nurses, physicians, managers or supervisors, and other hospital personnel. Because such diverse groups of harassers were included in the reports, it is difficult to conclude which groups were most likely to be harassers. In several studies participants were more likely to be harassed by patients or their families (Gleberzon et al., 2015; Levin \& Traub, 2006; Pai \& Lee, 2011; Wilkinson et al., 2006) than by coworkers. For example, in the Talas et al. (2011) study of staff in an emergency department in Turkey, the source of harassment was much more likely to be patients $(81.4 \%)$ or patients' companions (100\%) than physicians (13.9\%) or nurses (13.9\%). Conversely, in other studies, participants were most likely to be harassed by other healthcare workers (Çelik \& Çelik, 2007; Johnson, 2013). For example, a study conducted in Ghana revealed that nurses were more likely to be harassed by doctors (54.9\%) than patients (11.3\%) or their relations (18.3\%) (Boafo, Hancock, \& Gringart, 2016).

\section{Recipient Responses to Sexual Harassment}

All the reports contained findings related to how healthcare workers responded to incidents of sexual harassment. Most of the findings were presented as the percent of the sexual harassment recipients who reported a particular response. For this review, the responses were categorized as follows: harassment-related feelings, mental health effects, physical health effects, employmentrelated effects, and coping strategies. Because many harassment-related feelings and coping 
strategies were identified but experienced by a small percent of the samples, and because the purpose of the review was to identify common responses, findings in these two categories were discussed if at least $20 \%$ of the sample reported a particular response.

\section{Harassment-related Feelings}

In several studies, participants were queried about the feelings they experienced as a result of sexual harassment. Four of these studies reported the percent of sexual harassment recipients in the sample who experienced any one of an array of feelings as a result of the harassment. Table 3 reflects findings in which at least $20 \%$ of the sexual harassment recipients in each sample reported a particular feeling. Three of these studies revealed that over $20 \%$ of the recipients of sexual harassment experienced anger (Çelik \& Çelik, 2007; Johnson, 2013; Talas et al., 2011), and two studies revealed that over 20\% experienced fear (Çelik \& Çelik, 2007; Talas et al., 2011) and shock/astonishment (Talas et al., 2011; Johnson, 2013). The findings of the Talas et al. (2011) study indicated that over $20 \%$ of their participants experienced many other feelings as well. In that study, in addition to anger, fear, and shock/astonishment, over $20 \%$ of the participants also experienced disappointment, sadness, powerlessness, low self-esteem, anxiety, fury/hate, animosity, helplessness, despair, failure, feel lowly, guilt/shame, and disgust. Also of note is that $24.4 \%$ of the participants in the Johnson (2013) study reported feelings of depression.

The variation in these findings is likely due to the way feelings were assessed. For example, in the Levin and Traub (2006) study, open-ended questions were used to assess feelings, whereas in the Talas et al. (2011) study, a list of feelings was provided to the participants and they were asked to indicate which ones they experienced. This could account for why the findings of this study revealed that such a wide variety of feelings were experienced by over $20 \%$ of the sample and why some feelings, including sadness and anger, were experienced by over $80 \%$ of the 
sample. The findings of the Nielson et al. (2017) qualitative study of sexual harassment experienced by care workers in Denmark supported the quantitative findings of other studies as the care workers reported experiencing fear, shock, insecurity, powerlessness, shame, and selfblame as a result of the harassment.

\section{Mental Health Effects}

Several studies also examined negative mental health effects. Forty-four percent of the recipients of sexual harassment in the Çelik \& Çelik (2007) study, for example, indicated that the sexual harassment resulted in "disturbed" mental health, and $40.3 \%$ of the recipients of sexual harassment in the Pai and Lee (2011) study experienced stress symptoms that indicated the presence of post-traumatic stress disorder (PTSD). Findings of the Boafo et al. (2016) study were also suggestive of post-traumatic stress symptoms; $33.8 \%$ of the participants had repeating disturbing memories about the harassment, $46.4 \%$ avoided feelings or thoughts related to the harassment, and $66.2 \%$ were alert or watchful and on guard following the harassment. Yang et al. (2018) reported significant associations between annual frequency of sexual harassment and emotional exhaustion $(\mathrm{r}=0.253, \mathrm{p}=.0 .000)$ and depersonalization $(\mathrm{r}=0.179, \mathrm{p}=0.000)$ and the experience of at least one incident of sexual harassment and emotional exhaustion $(\mathrm{Z}=2.95$, $\mathrm{p}=0.000$ ). In the Demir and Rodwell (2012) study, external (e.g., by patients and visitors) verbal sexual harassment was associated with psychological distress with negative affectivity as a significant covariate $[\mathrm{F}(1,196)=5.63, \mathrm{p}<.05)]$.

\section{Physical Health Effects}

Three studies examined physical health responses to incidents of sexual harassment. Levin and Traub (2006) measured insomnia and fatigue as a response to sexual violence, but few participants (less than 8\%) reported these effects. In contrast, Çelik \& Çelik (2007) revealed that 
$40.3 \%$ of the recipients of sexual harassment experienced headaches in response to the harassment. Moreover, Takaki, Taniguchi, and Hirokawa (2013) reported that headache, stiffness of neck and shoulders, lumbago, and pain of two or more joints were significantly positively associated with sexual harassment in women [prevalence ratios (PR) at 95\% confidence interval $(\mathrm{CI})=1.08,1.03,1.05,1.09$, respectively)], whereas lumbago and pain of two or more joints were significantly positively associated with sexual harassment in men $[\mathrm{PR}$ at $95 \% \mathrm{CI}=1.07$ and 1.13 respectively].

\section{Employment-related Effects}

A few studies reported on the percent of the recipients of sexual harassment who experienced effects related to their employment. Levin \& Traub (2006) reported that a small group of qualified and student SLP/As (less than 13\%) who experienced sexual harassment reported experiencing distraction and decreased motivation at work. Moreover, four participants in the sample (7.1\%) had resigned from their jobs as a result of the harassment. Two studies indicated that sexual harassment influenced some nurses to leave, or to consider leaving, the profession (Çelik \& Çelik, 2007; MacKusick \& Minick, 2010). Wilkinson et al. (2006) reported that a small group of medical students who experienced unwanted sexual advances were put off the area of medicine that was the context of the harassment (9\%), took time off from medical school (7\%), or considered quitting medical school (5\%). In the Demir and Rodwell (2012) study, external (e.g., by patients or visitors) verbal sexual harassment was associated with lower organizational commitment with negative affectivity as a significant covariate $[F(1,202)=6.54, p<.051]$ and with lower job satisfaction levels with negative affectivity as a significant covariate $[\mathrm{F}(1,200)=7.60, \mathrm{p}<.051)]$ 


\section{Coping Strategies}

The majority of the reports $(n=10)$ indicated the percent of recipients of sexual harassment in the sample who engaged in a variety of coping strategies in response to the harassment. These coping strategies varied widely from taking no action to formally reporting an incident. Table 4 displays findings in which at least $20 \%$ of the sexual harassment recipients reported a particular coping strategy.

A number of studies revealed that some recipients of sexual harassment ignored the harassment. As reflected in Table 4, over $20 \%$ of the recipients of sexual harassment in seven studies ignored the harassment by doing nothing, pretending to not see it, or acting like it did not occur (Boafo et al., 2016; Çelik \& Çelik, 2007; Gleberzon et al., 2015; Levin \& Traub, 2006; Pai \& Lee, 2011; Talas et al., 2011; Ulusoy et al., 2011). Over 20\% of recipients of sexual harassment in five studies engaged in strategies to avoid the harasser such as leaving the scene, avoiding the harasser, or avoiding the department in which the harassment occurred (Çelik \& Çelik, 2007; Johnson, 2013; Talas et al., 2011, Ulusoy et al., 2011; Wilkinson et al., 2006).

Other studies indicated that some recipients of sexual harassment attempted to curtail the behavior of the harassers. As shown in Table 4, over $20 \%$ of the recipients of sexual harassment in five studies told the person to stop the behavior, defended themselves against the harasser physically or verbally, or rejected the harasser (Boafo et al., 2016; Gleberzon et al., 2015; Pai \& Lee, 2011; Ulusoy et al., 2011; Wilkinson et al., 2006).

Seeking support from others was a common response to sexual harassment. Three studies indicated that over $20 \%$ of the participants confided in, or got support from, friends or family (Johnson, 2013; Pai \& Lee, 2011; Wilkinson et al., 2006), and three studies indicated that over 
$20 \%$ of the participants confided in, or got support from, a colleague or co-worker (Boafo et al., 2016; Kvas \& Seljak, 2014; Pai \& Lee, 2011).

Some participants formally reported the harassment. Five studies indicated that over $20 \%$ of recipients of sexual harassment reported the harassment to an authority at their institution either verbally or by a formal report (Çelik \& Çelik, 2007; Kvas \& Seljak, 2014; Pai \& Lee, 2011; Talas et al., 2011; Ulusoy et al., 2011). Of note, however, are the findings of several studies indicating that reporting the harassment to managers or senior staff persons did not guarantee that action would be taken. In the Pai and Lee (2011) study, 57.5\% of the participants reported that no further action was taken after the nurse reported an incident of sexual harassment to a manager or other staff member. Kvas and Seljak (2014) identified several reasons why participants did not report acts of sexual violence. Over half (51.7\%) did not report an incident of harassment because they had had prior negative experiences with reporting or believed nothing would change. Other reasons they did not report the harassment included fear of losing one's job (25.0\%), fear of the person initiating violence (15.0\%), belief that the victim caused the violence (1.7\%), or other (6.7\%). Boafo et al. (2016) also identified reasons why recipients of sexual harassment did not report it: it was not important (80.6\%), such abuse is part of the job (11.3\%), I felt ashamed (22.6\%), I was afraid of negative consequences (3.2\%), no action will be taken if reported (19.4\%), did not know whom to report to (53.2\%), other reasons $(9.7 \%)$.

\section{Discussion}

The results of this review suggest that healthcare workers from around the world who are the recipients of sexual harassment in their workplaces respond in a variety of ways. Many experience a range of feelings after incidents of sexual harassment, with the most common being anger, fear, and shock. Findings indicate that healthcare workers may experience not only 
aversive feelings following incidents of sexual harassment but may suffer from negative mental health, physical health, and employment-related effects as well.

These findings can be placed in the context of the larger body of research that reveals that sexual harassment causes harm in a wide variety of workplaces and populations. For example, a metaanalysis of 49 primary studies with a total sample size of 89,382 workers revealed that sexual harassment experiences were negatively associated with psychological health (e.g., well-being and distress), physical health (e.g., health satisfaction, physical symptoms), and job-related outcomes (e.g., job satisfaction, organization commitment) (Chan, Lam, Chow, \& Cheung, 2008). Additional studies with healthcare workers would thus likely more definitively substantiate that sexual harassment can be harmful in these three domains.

The findings of the current review provide evidence that healthcare workers who are recipients of sexual harassment engage in a wide variety of coping strategies in response to the harassment. These findings also resonate with prior studies on coping with sexual harassment in different populations. Scarduzio, Sheff, \& Smith (2018), for example, in a sample of college students who had experienced online and face-to-face sexual harassment, found that that students used 16 coping strategies. The strategies were divided into categories based on the seminal coping model of Lazarus and Folkman (1984). Lazarus and Folkman distinguished problem-focused coping strategies, which include attempts to solve a stressful situation, from emotion-focused coping strategies, which include attempts to manage emotions that stem from the stressful situation. Scarduzio et al. (2018) divided the 16 coping strategies used by the college students into three types: active emotion-focused (e.g., communicating with someone for support and advice), passive emotion-focused (e.g., downplaying the seriousness of the sexual harassment situation), and problem-focused (e.g., confronting the harasser and telling him/her to stop or that the 
recipient is not interested). The major categories of coping strategies found in the current review could be divided into these categories: problem-solving (i.e., avoiding the harasser, confronting the harasser, reporting harassment to managers or senior persons), passive-emotion focused (i.e., ignoring the harasser/harassment), and active emotion-focused (i.e., telling or getting support from friends, family, or others; telling or getting support from colleagues or co-worker). However, the studies reviewed did not determine the effectiveness of coping strategies in mitigating negative effects, an important and complex issue. For example, while problemfocused coping is generally considered more effective, directly confronting an offender in the context of workplace sexual harassment may lead to increased risk for recipients (Scarduzio et al., 2018).

Some of the conclusions of the current review are tenuous as there are a number of limitations to the body of research reviewed. While the literature on workplace violence in healthcare is robust, the number of studies that focused specifically on recipient responses to sexual harassment was relatively small, and thus this review included only fifteen studies. The strategic decision to include reports published after 2005 resulted in the inclusion of a number of reports that were more than a decade old, which limits conclusions about healthcare workers' contemporary responses to sexual harassment, especially in light of the \#MeToo movement. While the studies were conducted around the world, no single country or region produced a critical mass of studies so that strong conclusions could be made about cultural influences or regional differences in recipient responses to sexual harassment.

Moreover, many of the studies had methodological limitations. Most studies used researcherdeveloped instruments or adaptations of previously used instruments and little psychometric evidence to support the validity of the instruments was provided. All of the quantitative studies 
were cross-sectional and primarily used descriptive statistics to determine what percentage of the recipients of sexual harassment in each sample reported each response. The studies thus do not allow claims of causality between sexual harassment and recipient responses. Cross-sectional designs also do not allow determination of how responses change over time. For example, it is likely that recipients have an acute reaction at the time of the harassment that will evolve as time passes and other experiences intervene.

The designs of the studies also did not allow determination of how the nature of the harassment (e.g., verbal versus physical) as well as its severity, frequency, and duration might affect recipient responses. A one-time incident of offensive sexual humor, a one-time sexual assault, and on-going sexual demands, for example, would all likely elicit varying responses in participants. Moreover, while participants were often asked to indicate the source of the harasser, the studies did not examine differential effects by source, despite that it is likely the role of the harasser would influence recipient responses. For example, one would expect that sexual harassment by patients and families is experienced differently than sexual harassment by colleagues or supervisors and may well call for different coping strategies. Moreover, the studies did not address how the response of the institution, such as actions taken in response to complaints, influenced recipient responses.

More research is needed so that a model that accounts for the complex associations among the characteristics of the harassment, institutional responses to the harassment, and the recipients' responses as they change over time could be developed. Such a model could advance our understanding of the experiences of sexual harassment of healthcare workers and suggest target areas for prevention and intervention initiatives. Moreover, despite that it is critical that we understand sexual harassment from the perspectives of those who experience it, only two 
qualitative studies were found that met the review criteria. Additional qualitative studies that produce in-depth narratives of experiences of sexual harassment in a variety of contexts will provide findings that enrich the explanatory model.

Despite these limitations, the review does substantiate that healthcare workers who experience sexual harassment experience a number of adverse feelings and some experience emotional and physical harm and negative consequences for their employment. The results of this review thus support industry demands for health system reviews of institutional policies related to sexual harassment, the implementation of zero-tolerance policies, the creation of effective prevention initiatives across all healthcare settings, and support for healthcare workers who were harmed by sexual harassment (Nelson, 2018; von Gruenigen \& Karlan, 2018). Experts suggest, for example, that counselors who understand the emotional sequelae of sexual harassment be made available to employees (Cortina \& Wasti, 2005).

\section{Conclusion}

Healthcare workers who experience sexual harassment experience aversive feelings and some experience harmful health- and employment-related harms. Recipients of sexual harassment engage in a wide variety of passive and active coping strategies. Research studies with more sophisticated designs are needed to understand complex relationships between variables regarding the nature of the harassment, institutional responses to harassment, and recipient responses. The results of this review nonetheless indicate that evidence-based prevention and intervention approaches are needed in all healthcare contexts. While the \#Me-Too Movement continues to create renewed focus on the problem of sexual harassment in the workplace, much work remains if the sexual harassment of healthcare workers and the negative consequences associated with it are to be prevented. 


\section{References}

Allen, N. J., \& Meyer, J. P. (1990). The measurement and antecedents of affective, continuance and normative commitment to the organization. Journal of Occupational Psychology, 63(1), 118. doi:10.1111/j.2044-8325.1990.tb00506.x

Boafo, I. M., Hancock, P., \& Gringart, E. (2016). Sources, incidence and effects of non-physical workplace violence against nurses in Ghana. Nursing Open, 3(2), 99-109. doi:10.1002/nop2.43

Brayfield, A. H., \& Rothe, H. F. (1951). An index of job satisfaction. Journal of Applied Psychology, 35(5), 307-311. doi:10.1037/h0055617

Çelik, Y., \& Çelik, S. S. (2007). Sexual harassment against nurses in Turkey. Journal of Nursing Scholarship, 39(2), 200-206. doi:10.1111/j.1547-5069.2007.00168.x

Chan, D. K.-S., Lam, C. B., Chow, S. Y., \& Cheung, S. F. (2008). Examining the job-related, psychological, and physical outcomes of workplace sexual harassment: A meta-analytic Review. Psychology of Women Quarterly, 32(4), 362-376. doi:10.1111/j.1471-6402.2008.00451.x

Cortina, L. M., \& Wasti, S. A. (2005). Profiles in coping: Responses to sexual harassment across persons, organizations, and cultures. Journal of Applied Psychology, 90(1), 182-192. doi:10.1037/0021-9010.90.1.182

Demir, D., \& Rodwell, J. (2012). Psychosocial antecedents and consequences of workplace aggression for hospital nurses. Journal of Nursing Scholarship, 44(4), 376-384. doi:10.1111/j.1547-5069.2012.01472.x 
di Martino, V. (2003). Relationship between work stress and workplace violence in the health sector. ILO/ICN/WHO/PSI Joint Programme on Workplace Violence in the Health Sector, Geneva.

Einarsen, S., \& Raknes, B. I. (1997). Harassment in the workplace and the victimization of men. Violence and Victims, 12(3), 247-263.

Freischlag, J. A., \& Faria, P. (2018). It is time for women (and men) to be brave: A consequence of the \#MeToo movement. Journal of the American Medical Association, 319(17), 1761-1762. doi:10.1001/jama.2018.4059

Gleberzon, B., Statz, R., \& Pym, M. (2015). Sexual harassment of female chiropractors by their patients: A pilot survey of faculty at the Canadian Memorial Chiropractic College. Journal of the Canadian Chiropractic Association, 59(2), 111-121.

Hesketh, K. L., Duncan, S. M., Estabrooks, C. A., Reimer, M. A., Giovannetti, P., Hyndman, K., \& Acorn, S. (2003). Workplace violence in Alberta and British Columbia hospitals. Health Policy, 63(3), 311-321.

ILO/ICN/WHO/PSI. (2003). Workplace violence in the health sector country case studyquestionnaire. ILO/ICN/WHO/PSI, Geneva.

Jagsi, R. (2018). Sexual harassment in medicine — \#MeToo. The New England Journal of Medicine, 378(3), 209-211. doi:10.1056/NEJMp1715962

Johnson, K. (2013). Sexual harassment against nursing students: A case study of Nigeria. Gender \& Behaviour, 11(1), 5220-5236. 
Kessler, R., \& Mroczek, D. (1994). Final versions of our non-specific psychological distress scale (Vol. 10). Ann Arbor, MI: Institute for Social Research.

Kvas, A., \& Seljak, J. (2014). Unreported workplace violence in nursing. International Nursing Review, 61(3), 344-351. doi:10.1111/inr.12106

Langone, A. (2018, March 22). \#MeToo and Time's Up founders explain the difference between the 2 movements - and how they're alike. Time. Retrieved from http://time.com/5189945/whats-the-difference-between-the-metoo-and-times-up-movements/

Lazarus, R., \& Folkman, S. (1984). Stress, appraisal, and coping. New York: Springer Publishing Company

Levin, K., \& Traub, L. (2006). Inappropriate sexual behaviours experienced by speech-language pathologists and audiologists in South Africa. South African Journal of Communication Disorders, 53, 5-15.

MacKusick, C. I., \& Minick, P. (2010). Why are nurses leaving? Findings from an initial qualitative study on nursing attrition. Medsurg Nursing, 19(6), 335-340.

McComas, J., Hebert, C., Giacomin, C., Kaplan, D., \& Dulberg, C. (1993). Experiences of student and practicing physical therapists with inappropriate patient sexual behavior. Physical Therapy, 73(11), 762-769; discussion 769-770.

Nelson, R. (2018). Sexual harassment in nursing: A long-standing, but rarely studied problem. American Journal of Nursing, 118(5), 19-20. doi:10.1097/01.NAJ.0000532826.47647.42

Nielson, M. B. D., Kjaer, S., Aldrich, P. T., Madsen, I. E. H., Friborg, M. K., Rugulies, R., \& Folker, A. P. (2017). Sexual harassment in care work - Dilemmas and consequences: A 
qualitative investigation. International Journal of Nursing Studies, 70, 122-130.

doi:10.1016/j.ijnurstu.2017.02.018

Pai, H. C., \& Lee, S. (2011). Risk factors for workplace violence in clinical registered nurses in Taiwan. Journal of Clinical Nursing, 20(9-10), 1405-1412. doi:10.1111/j.13652702.2010.03650.x

Phillips, S. P., \& Schneider, M. S. (1993). Sexual harassment of female doctors by patients. The New England Journal of Medicine, 329(26), 1936-1939. doi:10.1056/nejm199312233292607

Pina, A., \& Gannon, T. A. (2012). An overview of the literature on antecedents, perceptions and behavioural consequences of sexual harassment. Journal of Sexual Aggression, 18(2), 209-232. doi:10.1080/13552600.2010.501909

Scarduzio, J. A., Sheff, S. E., \& Smith, M. (2018). Coping and sexual harassment: How victims cope across multiple settings. Archives of Sexual Behavior, 47(2), 327-340. doi:10.1007/s10508017-1065-7

Schutte, N., Toppinen, S., Kalimo, R., \& Schaufeli, W. (2000). The factorial validity of the Maslach Burnout Inventory-General Survey (MBI-GS) across occupational groups and nations. Journal of Occupational and Organizational Psychology, 73(1), 53-66. doi:10.1348/096317900166877

Spector, P. E., Zhou, Z. E., \& Che, X. X. (2014). Nurse exposure to physical and nonphysical violence, bullying, and sexual harassment: A quantitative review. International Journal of Nursing Studies, 51(1), 72-84. doi:10.1016/j.jinurstu.2013.01.010 
Takaki, J., Taniguchi, T., \& Hirokawa, K. (2013). Associations of workplace bullying and harassment with pain. International Journal of Environmental Research and Public Health, 10(10), 4560-4570. doi:10.3390/ijerph10104560

Talas, M. S., Kocaoz, S., \& Akguc, S. (2011). A survey of violence against staff working in the emergency department in Ankara, Turkey. Asian Nursing Research, 5(4), 197-203. doi:10.1016/j.anr.2011.11.001

Ulusoy, H., Swigart, V., \& Erdemir, F. (2011). Think globally, act locally: Understanding sexual harassment from a cross-cultural perspective. Medical Education, 45(6), 603-612. doi:10.1111/j.1365-2923.2010.03918.x

von Gruenigen, V. E., \& Karlan, B. Y. (2018). Sexual harassment in the work place: Its impact on gynecologic oncology and women's health. Gynecologic Oncology, 149(2), 227-229. doi:10.1016/j.ygyno.2018.02.018

Watson, D., Clark, L. A., \& Tellegen, A. (1988). Development and validation of brief measures of positive and negative affect: The PANAS scales. Journal of Personality and Social Psychology, 54(6), 1063-1070. doi:10.1037/0022-3514.54.6.1063

Whittemore, R., \& Knafl, K. (2005). The integrative review: Updated methodology. Journal of Advanced Nursing, 52(5), 546-553. doi:10.1111/j.1365-2648.2005.03621.x

Wilkinson, T. J., Gill, D. J., Fitzjohn, J., Palmer, C. L., \& Mulder, R. T. (2006). The impact on students of adverse experiences during medical school. Medical Teacher, 28(2), 129-135. doi:10.1080/01421590600607195 
Williams, T. H., de Seriere, J., \& Boddington, L. (1999). Inappropriate sexual behaviour experienced by speech-language therapists. International Journal of Language and Communication Disorders, 34(1), 99-111.

Willness, C. R., Steel, P., \& Lee, K. (2007). A meta-analysis of the antecedents and consequences of workplace sexual harassment. Personnel Psychology, 60(1), 127-162. doi:10.1111/j.1744-6570.2007.00067.x

Yang, B. X., Stone, T. E., Petrini, M. A., \& Morris, D. L. (2018). Incidence, type, related factors, and effect of workplace violence on mental health nurses: A cross-sectional survey. Archives of Psychiatric Nursing, 32(1), 31-38. doi:10.1016/j.apnu.2017.09.013 
Table 1. Summary Table of Reports of Studies Investigating Healthcare Workers Responses to Sexual Harassment, 2005 -2018

\begin{tabular}{|c|c|c|c|c|c|c|c|}
\hline Citation & Purpose & Design & $\begin{array}{l}\text { Setting, } \\
\text { Population, } \\
\text { Sample }\end{array}$ & $\begin{array}{l}\text { Sexual Harassment } \\
\text { Variables/Measures }\end{array}$ & \begin{tabular}{|l|} 
Responses to Sexual \\
Harassment \\
Variables/Measures
\end{tabular} & $\begin{array}{l}\text { Incidence/ } \\
\text { Prevalence of } \\
\text { Sexual } \\
\text { Harassment }\end{array}$ & Responses to Sexual Harassment \\
\hline
\end{tabular}




\begin{tabular}{|c|c|c|c|c|c|c|c|}
\hline & & & & & & \begin{tabular}{|l|} 
clients- other \\
sources were \\
parents, spouses, \\
and children of \\
clients \\
$8.9 \%$ of \\
qualified \\
SLP/As were \\
harassed by \\
employers and \\
colleagues in \\
senior positions \\
5.3\% of the \\
qualified \\
SLP/As had \\
been severely \\
harassed by \\
hospital porters
\end{tabular} & \\
\hline $\begin{array}{l}\text { Wilkinson, } \\
\text { Gill, Fitzjohn, } \\
\text { Palmer, \& } \\
\text { Mulder (2006) }\end{array}$ & $\begin{array}{l}\text { To determine the } \\
\text { consequences for, } \\
\text { and coping methods } \\
\text { used by, medical } \\
\text { students who } \\
\text { experience adverse } \\
\text { experiences during } \\
\text { training. } \\
\text { Adverse experiences } \\
\text { could include been } \\
\text { yelled or sworn at, } \\
\text { humiliated or } \\
\text { degraded; } \\
\text { experienced unfair } \\
\text { treatment because of } \\
\text { gender; experienced } \\
\text { unfair treatment } \\
\text { because of race; been } \\
\text { threatened with } \\
\text { physical harm; been } \\
\text { physically hit; } \\
\text { experienced } \\
\text { discomfort listening } \\
\text { to sexual humour or } \\
\text { experienced }\end{array}$ & \begin{tabular}{|l|} 
Cross- \\
sectional \\
survey
\end{tabular} & $\begin{array}{l}\text { The four medical } \\
\text { schools in New } \\
\text { Zealand } \\
1,384 \text { medical } \\
\text { students }\end{array}$ & $\begin{array}{l}\text { Sexual humour } \\
\text { Unwanted sexual } \\
\text { advances } \\
\text { (Researcher- } \\
\text { developed survey) }\end{array}$ & $\begin{array}{l}\text { Impact of the worst } \\
\text { episode } \\
\left(\text { Same survey }^{1}\right)\end{array}$ & $\begin{array}{l}28 \% \text { had } \\
\text { experienced } \\
\text { discomfort } \\
\text { listening to } \\
\text { sexual humour } \\
\text { during the } \\
\text { course of } \\
\text { medical school } \\
\\
14 \% \text { had } \\
\text { experienced } \\
\text { unwanted sexual } \\
\text { advances during } \\
\text { the course of } \\
\text { medical school } \\
\text { Sources of } \\
\text { unwanted sexual } \\
\text { advances: senior } \\
\text { doctor }(8 \%), \\
\text { registrar }(8 \%), \\
\text { house surgeon } \\
\text { (5\%), medical } \\
\text { student (47\%), } \\
\text { nurse (7\%), } \\
\text { patient (54\%), }\end{array}$ & $\begin{array}{l}\text { Percentage of respondents who rated single } \\
\text { episode that bothered them most as } 4 \text { or } 5 \text { on a } 5 \text { - } \\
\text { point scale (not at all upsetting or important to } \\
\text { very upsetting or important): experiencing } \\
\text { unwanted sexual advances (39\%) and } \\
\text { experiencing discomfort from sexual humour } \\
(17 \%) \text {. } \\
\text { Discomfort from adverse experience that bothered } \\
\text { participants the most: sexual humour - put behind } \\
\text { me immediately (71\%), several hours to get over } \\
(18 \%) \text {, several days to get over (4\%), at least a } \\
\text { month to get over (4\%), will always be with me } \\
(1 \%) \text {; unwanted sexual advances - put behind me } \\
\text { immediately (41\%), several hours to get over } \\
(23 \%) \text {, several days to get over (20\%), at least a } \\
\text { month to get over (7\%), will always be with me } \\
(7 \%) \text {. } \\
\text { Consequences of the adverse experience that } \\
\text { affected participants the most: sexual humour - } \\
\text { episode motivated me to learn more (10\%), } \\
\text { avoided department/person (41\%), sought } \\
\text { help/talked to others (23\%), was put off this area } \\
\text { medicine (10\%), took time off medical school } \\
(3 \%) \text {, considered quitting ( } 4 \%) \text {, became more }\end{array}$ \\
\hline
\end{tabular}




\begin{tabular}{|c|c|c|c|c|c|c|c|}
\hline & $\begin{array}{l}\text { unwanted sexual } \\
\text { advances by a senior } \\
\text { doctor, registrar, } \\
\text { house surgeon, } \\
\text { fellow student, } \\
\text { nurse, or patient. }\end{array}$ & & & & & not stated $(0 \%)$ & $\begin{array}{l}\text { assertive (13\%), became more withdrawn/isolated } \\
(10 \%), \text { felt I was improved/a better person }(8 \%), \\
\text { confronted the person }(6 \%) \text {; unwanted sexual } \\
\text { advances - episode motivated me to learn more } \\
(2 \%), \text { avoided department/person }(61 \%) \text {, sought } \\
\text { help/talked to others }(50 \%) \text {, was put off this area } \\
\text { medicine }(9 \%), \text { took time off medical school (7\%), } \\
\text { considered quitting (5\%), became more assertive } \\
(45 \%), \text { became more withdrawn/isolated (16\%), } \\
\text { felt I was improved/a better person (14\%), } \\
\text { confronted the person }(20 \%) .\end{array}$ \\
\hline \begin{tabular}{|l|} 
Çelik \& Çelik \\
$(2007)$
\end{tabular} & $\begin{array}{l}\text { Identify the } \\
\text { prevalence and } \\
\text { sources of sexual } \\
\text { harassment against } \\
\text { nurses in Turkey, its } \\
\text { consequences, and } \\
\text { factors affecting } \\
\text { harassment } \\
\text { experiences. }\end{array}$ & \begin{tabular}{|l|} 
Cross- \\
sectional \\
survey
\end{tabular} & $\begin{array}{l}8 \text { Ministries of } \\
\text { Health hospitals in } \\
\text { Turkey } \\
622 \text { nurses }\end{array}$ & $\begin{array}{l}\text { Types of sexual } \\
\text { harassment: } \\
\text { unwanted sexual } \\
\text { jokes, stories, } \\
\text { questions, or words; } \\
\text { receiving unwanted } \\
\text { mail or telephone } \\
\text { calls; being shown } \\
\text { someone's body } \\
\text { sexually; having the } \\
\text { participants' body } \\
\text { touched; or } \\
\text { experiencing an } \\
\text { attempted assault } \\
\text { and sources of } \\
\text { sexual harassment } \\
\text { (colleagues, } \\
\text { physicians, other } \\
\text { hospital personnel, } \\
\text { patients, or patients' } \\
\text { relatives } \\
\\
\text { (Sexual Harassment } \\
\text { Questionnaire: } \\
\text { researcher- } \\
\text { developed survey) }\end{array}$ & $\begin{array}{l}\text { Physical and mental } \\
\text { health, headaches, } \\
\text { work productivity, } \\
\text { thoughts of leaving } \\
\text { nursing } \\
\left(\text { Same survey }^{1}\right)\end{array}$ & \begin{tabular}{|l|}
$37 \%$ had ever \\
experienced \\
sexual \\
harassment \\
Sources: other \\
nurses $(51.1 \%)$, \\
physicians \\
$(77.1 \%)$, other \\
hospital \\
personnel \\
$(29.4 \%)$, patients \\
$(43.3 \%)$, \\
patients' \\
relatives $(34.2 \%)$
\end{tabular} & $\begin{array}{l}\text { All participants who were sexually harassed said } \\
\text { that sexual harassment affected their mental and } \\
\text { physical health negatively. Negative effects: } \\
\text { disturbed mental health (44\%), headache (40.3\%), } \\
\text { decreased work productivity (45.0\%) and thoughts } \\
\text { of leaving nursing ( } 37.2 \%) \text {. More than one-third } \\
\text { reported sexual harassment affected their social } \\
\text { life, relationships, and family life negatively. } \\
\text { Feelings after sexual harassment: (69.7\%), fear } \\
(23.4 \%), \text { helplessness (17.3\%), depression } \\
(10.8 \%), \text { belittlement or humiliation (10.8\%). } \\
\text { Coping methods: "do nothing" (59.3\%), putting up } \\
\text { a barrier (43.3\%), pretending not to see the } \\
\text { harassment }(30.7 \%), \text { using drugs to aid in sleeping } \\
(24.2 \%), \text { reporting to a manager (21.6\%). }\end{array}$ \\
\hline $\begin{array}{l}\text { MacKusick \& } \\
\text { Minick (2010) }\end{array}$ & $\begin{array}{l}\text { Identify the factors } \\
\text { influencing the } \\
\text { decision of RNs to } \\
\text { leave clinical nursing } \\
\text { practice. }\end{array}$ & $\begin{array}{l}\text { Phenome } \\
\text { nology }\end{array}$ & $\begin{array}{l}\text { Southeastern } \\
\text { United States } \\
\\
10 \text { licensed RNs } \\
\text { with a minimum of } \\
1 \text { year of clinical } \\
\text { practice and no } \\
\text { clinical practice in } \\
\text { the last } 6 \text { months }\end{array}$ & $\begin{array}{l}\text { Semi-structured } \\
\text { interviews including } \\
\text { questions about why } \\
\text { the participants } \\
\text { decided to leave } \\
\text { bedside nursing }\end{array}$ & & \begin{tabular}{|l|} 
Participants \\
described sexual \\
harassment by \\
colleagues and \\
physicians
\end{tabular} & $\begin{array}{l}\text { Unfriendly workplace included incidents of sexual } \\
\text { harassment or gender abuse with co-workers. } \\
\text { These behaviors were accepted as the norm on } \\
\text { their units and influenced decision to leave } \\
\text { nursing. Participants described how managers did } \\
\text { not address inappropriate behaviors. }\end{array}$ \\
\hline
\end{tabular}




\begin{tabular}{|c|c|c|c|c|c|c|c|}
\hline $\begin{array}{l}\text { Pai \& Lee } \\
(2011)\end{array}$ & $\begin{array}{l}\text { To determine the risk } \\
\text { factors and mental } \\
\text { health consequences } \\
\text { of physical and } \\
\text { psychological } \\
\text { violence for clinical } \\
\text { nurses working in } \\
\text { healthcare settings in } \\
\text { Taiwan. }\end{array}$ & $\begin{array}{l}\text { Cross- } \\
\text { sectional } \\
\text { survey }\end{array}$ & $\begin{array}{l}\text { Taiwan Nurses } \\
\text { Association } \\
521 \text { nurses }\end{array}$ & $\begin{array}{l}\text { Sexual harassment: } \\
\text { unwanted, } \\
\text { unreciprocated or } \\
\text { unwelcome } \\
\text { behavior of a sexual } \\
\text { nature that is } \\
\text { offensive to the } \\
\text { person involved and } \\
\text { that that causes that } \\
\text { person to feel } \\
\text { threatened, } \\
\text { humiliated or } \\
\text { embarrassed } \\
\text { (Workplace } \\
\text { Violence } \\
\text { Questionnaire, } \\
\text { ILO/ICN/WHO/PSI } \\
\text {, 2003) }\end{array}$ & $\begin{array}{l}\text { Post-traumatic } \\
\text { stress disorder: } \\
\text { rehearsal, } \\
\text { avoidance, super- } \\
\text { alert, effort } \\
\text { Responses } \\
\text { Research-developed } \\
\text { survey compatible } \\
\text { with diagnostic } \\
\text { criteria for PTSD: } \\
\text { four items measured } \\
\text { on a 5-poiint Likert } \\
\text { scale (1= not at all } \\
\text { bothered, 5 = } \\
\text { extremely } \\
\text { bothered). }\end{array}$ & $\begin{array}{l}12.9 \% \text { of } \\
\text { participants had } \\
\text { experienced } \\
\text { sexual } \\
\text { harassment in } \\
\text { the last } 12 \\
\text { months } \\
\\
\text { Perpetrator of } \\
\text { sexual } \\
\text { harassment: } \\
\text { patient/client } \\
(44.8 \%), \\
\text { relatives of } \\
\text { patients }(11.9 \%), \\
\text { staff member } \\
(7.5 \%), \text { external } \\
\text { colleague/ } \\
\text { worker }(22.4 \%), \\
\text { management/ } \\
\text { supervisor } \\
(13.4 \%)\end{array}$ & $\begin{array}{l}40.3 \% \text { of participants exposed to sexual } \\
\text { harassment had a PTSD score higher than } 14 \\
\text { (range } 4 \text { to } 20 \text {; score over } 14 \text { indicates presence of } \\
\text { PTSD). } \\
57.5 \% \text { of participants exposed to sexual } \\
\text { harassment reported that no action was taken after } \\
\text { the nurse reported the incident to the manager or } \\
\text { the staff member. } \\
\\
\text { Actions taken included: took no action (26.9\%), } \\
\text { tried to pretend it never happened (28.4\%), told } \\
\text { the person to stop (68.7\%), told friends/family } \\
\text { (76.1\%), sought counseling (16.4\%), told a } \\
\text { colleague (70.2\%), reported it to the senior staff } \\
\text { member (70.2\%), transferred to another position } \\
\text { (1.5\%), sought help form association ( } 7.5 \%), \\
\text { completed incident/accident form (20.9\%), } \\
\text { pursued prosecution (17.9\%). } \\
\text { No action was taken to investigate ( } 57.5 \%) \text {. } \\
\text { Author- How is this different than your } 2^{\text {nd }} \\
\text { statement? Please advise if we should further } \\
\text { define or remove. }\end{array}$ \\
\hline
\end{tabular}




\begin{tabular}{|c|c|c|c|c|c|c|c|}
\hline $\begin{array}{l}\text { Talas, Kockõz, } \\
\text { \& Akgüç } \\
(2011)\end{array}$ & \begin{tabular}{|l|} 
Identify the \\
proportion of staff \\
subjected to the \\
types of violence, its \\
sources, factors \\
affecting violence \\
experiences, \\
reporting the \\
incidence and \\
emotions of the \\
victims after \\
violence
\end{tabular} & \begin{tabular}{|l|} 
Cross- \\
sectional \\
survey
\end{tabular} & $\begin{array}{l}\text { Emergency } \\
\text { departments of six } \\
\text { hospitals (three } \\
\text { university, three } \\
\text { state) in Ankara, } \\
\text { Turkey } \\
270 \text { staff } \\
\text { (physicians, } \\
\text { nurses, health } \\
\text { officer/technicians, } \\
\text { clerks, security } \\
\text { officers, } \\
\text { housekeepers) }\end{array}$ & \begin{tabular}{|l|} 
Sexual harassment: \\
being subjected to \\
unwanted sexual \\
jokes, stories, \\
questions or words; \\
being unwillingly \\
asked out; receiving \\
unwanted mail or \\
telephone calls; \\
being shown \\
someone's body \\
sexually; having \\
their body touched, \\
or experiencing an \\
attempted assault) \\
(36-item \\
questionnaire \\
consisting of 28 \\
close-ended and 8 \\
open-ended items; \\
based on the \\
literature and \\
adapted from Senol- \\
Celik and Bayraktar \\
questionnaire, 2004)
\end{tabular} & $\begin{array}{l}\text { Coping methods } \\
\text { Emotions } \\
\left(\text { Same survey }^{1}\right)\end{array}$ & \begin{tabular}{|l|}
$15.9 \%$ of \\
participants had \\
experienced \\
sexual \\
harassment in \\
the previous year \\
Sources: patients \\
$(81.4 \%)$, \\
patient's \\
companions \\
$(100.0 \%)$, \\
physicians \\
$(13.9 \%)$, nurses \\
$(13.9 \%)$, \\
managers of \\
nursing $(2.3 \%)$, \\
managers of \\
physicians \\
$(11.6 \%)$, \\
medical office \\
and emergency \\
medical \\
technicians \\
$(4.6 \%)$, clerks \\
$(4.6 \%)$, security \\
officers (6.9\%), \\
housekeepers \\
$(0.0 \%)$
\end{tabular} & 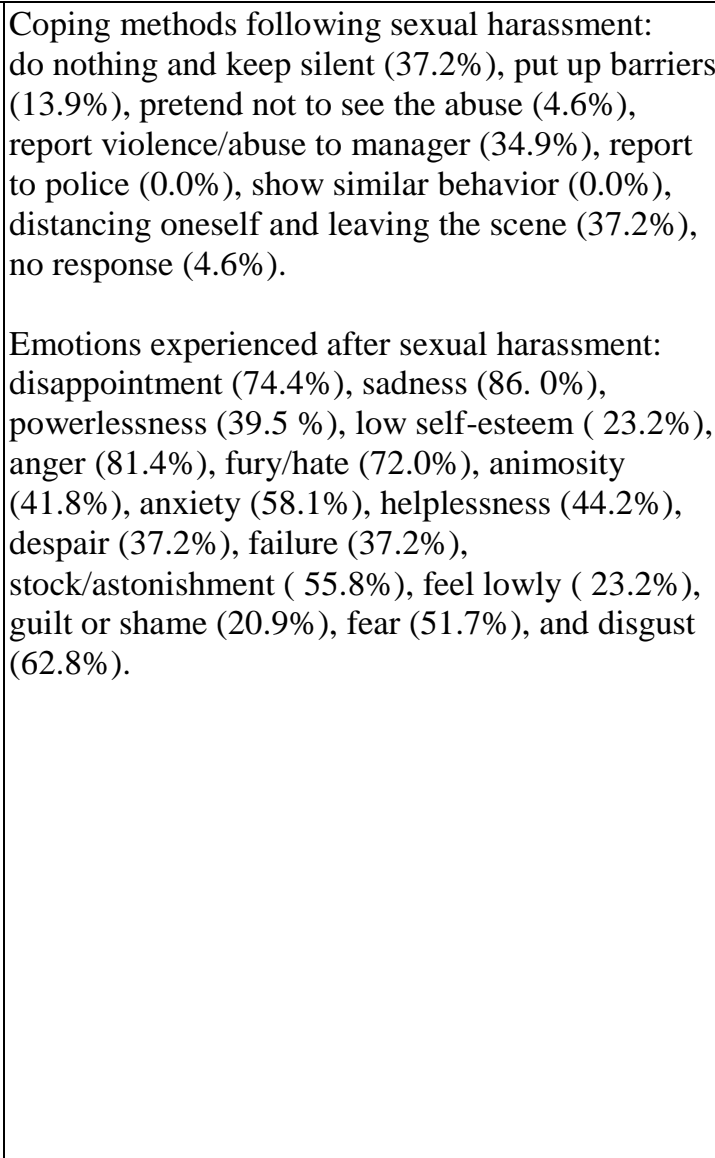 \\
\hline \begin{tabular}{|l} 
Ulusoy, \\
Swigart, \& \\
Erdemir (2011)
\end{tabular} & $\begin{array}{l}\text { Describe the sexual } \\
\text { harassment of female } \\
\text { doctors-in-training } \\
\text { by male patients and } \\
\text { their relatives in } \\
\text { Turkey. }\end{array}$ & $\begin{array}{l}\text { Cross- } \\
\text { sectional } \\
\text { survey } \\
\text { (with } \\
\text { open- } \\
\text { ended } \\
\text { items) }\end{array}$ & $\begin{array}{l}\text { Hospital in Turkey } \\
49 \text { doctors-in- } \\
\text { training }\end{array}$ & $\begin{array}{l}\text { Occurrence and } \\
\text { types of sexual } \\
\text { harassment: gazing } \\
\text { at the doctor in a } \\
\text { lewd manner, } \\
\text { asking about private } \\
\text { sexual matters, } \\
\text { asking for dates, } \\
\text { making threats or } \\
\text { swearing in a sexual } \\
\text { nature, touching the } \\
\text { doctor's body, } \\
\text { exhibition or } \\
\text { attempted exhibition } \\
\text { of genitals, stalking } \\
\text { the doctor, } \\
\text { requesting that the }\end{array}$ & $\begin{array}{l}\text { Reactions (methods } \\
\text { of coping) } \\
\text { Precautions taken } \\
\left(\text { Same survey }{ }^{1}\right)\end{array}$ & $\left|\begin{array}{l}67.3 \% \text { had been } \\
\text { sexually } \\
\text { harassed by a } \\
\text { patient or a } \\
\text { patient's relative } \\
\text { at some point in } \\
\text { their career }\end{array}\right|$ & $\begin{array}{l}\text { Coping with or reacting to the sexual harassment: } \\
\text { discharging or asking to discharge the harasser } \\
(24.2 \%) \text {, stopping all contact with the harasser } \\
(24.2 \%) \text {, showing rejection verbally or physically } \\
(21.2 \%) \text {, behaving as it nothing had happened } \\
(21.2 \%) \text {, asking for help from managers or } \\
\text { colleagues ( } 12.1 \%) \text {, showing a sense of humor, } \\
\text { trying to make a joke, trying to turn the } \\
\text { conversation to a different subject (9.1\%), } \\
\text { showing a hostile attitude (6.1\%). } \\
\text { Precautions taken: the patient-doctor relationship - } \\
\text { paying attention to one's own verbal and non- } \\
\text { verbal communication, behaving or talking with } \\
\text { patients and relatives seriously, preserving the } \\
\text { professional relationship; dressing - paying } \\
\text { attention to clothes; wearing high collars, long }\end{array}$ \\
\hline
\end{tabular}




\begin{tabular}{|c|c|c|c|c|c|c|c|}
\hline & & & & \begin{tabular}{|l|} 
doctor touch the \\
patient's private \\
parts, making sexual \\
jokes or remarks, \\
hugging in a sexual \\
manner, trying to \\
pull the doctor into \\
the patient's bed, \\
attempting rape \\
(Researcher- \\
developed survey, \\
with open-ended \\
items)
\end{tabular} & & & $\begin{array}{l}\text { skirts, pants, long-sleeved shirts; not wearing tight } \\
\text { or eye-catching clothes; not being alone with } \\
\text { patients - asking a nurse or another health care } \\
\text { work to remain in the room during the } \\
\text { examination of male patients; placing physical } \\
\text { barriers between the doctor and patient or relatives } \\
\text { - trying to be close physically to patients or } \\
\text { relatives, arranging the doctor's chair and table at } \\
\text { a distance from the patient }\end{array}$ \\
\hline $\begin{array}{l}\text { Demir \& } \\
\text { Rodwell } \\
\text { (2012) }\end{array}$ & $\begin{array}{l}\text { To test a full model } \\
\text { of the antecedents to } \\
\text { and consequences of } \\
\text { various forms of } \\
\text { workplace violence, } \\
\text { considering } \\
\text { psychosocial factors, } \\
\text { for nursing staff. }\end{array}$ & \begin{tabular}{|l|} 
Cross- \\
sectional \\
survey
\end{tabular} & $\begin{array}{l}\text { Large Australian } \\
\text { hospital } \\
207 \text { nurses and } \\
\text { midwives }\end{array}$ & \begin{tabular}{|l|}
$\begin{array}{l}\text { Internal (to the } \\
\text { organization - e.g., } \\
\text { coworker, } \\
\text { supervisor) verbal } \\
\text { sexual harassment }\end{array}$ \\
$\begin{array}{l}\text { External (to the } \\
\text { organization - e.g., } \\
\text { patients, visitors, } \\
\text { family) sexual } \\
\text { harassment } \\
\text { Adapted version of } \\
\text { scale by Hesketh et } \\
\text { al. (2003) }\end{array}$
\end{tabular} & 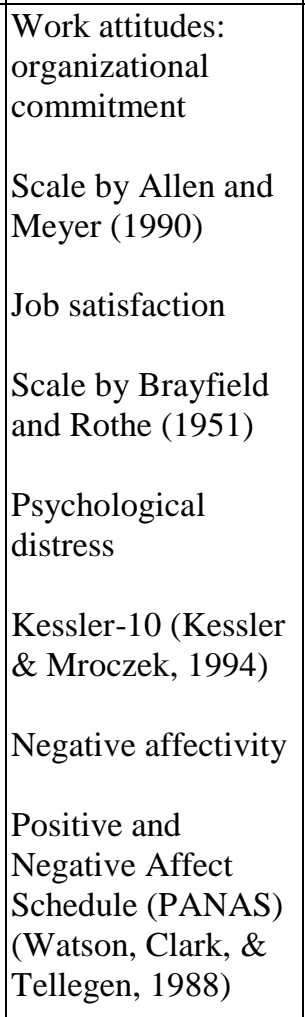 & \begin{tabular}{|l}
$2.0 \%$ \\
experienced \\
internal verbal \\
sexual \\
harassment \\
\\
$2.9 \%$ \\
experienced \\
external verbal \\
sexual \\
harassment
\end{tabular} & $\begin{array}{l}\text { External verbal sexual harassment was associated } \\
\text { with organizational commitment with negative } \\
\text { affectivity as a significant covariate }[\mathrm{F}(1,202) \\
=6.54, \mathrm{p}, .051] . \\
\text { External verbal sexual harassment was associated } \\
\text { with job satisfaction levels with negative } \\
\text { affectivity as a significant covariate } \\
{[\mathrm{F}(1,200)=7.60, \mathrm{p}<.051) .} \\
\\
\text { External verbal sexual harassment was associated } \\
\text { with psychological distress with negative } \\
\text { affectivity as a significant covariate } \\
{[\mathrm{F}(1,196)=5.63, \mathrm{p}<.05) .}\end{array}$ \\
\hline Johnson (2013) & $\begin{array}{l}\text { Find out the } \\
\text { prevalence of } \\
\text { unwarranted sexual } \\
\text { behaviors against } \\
\text { student nurses in }\end{array}$ & \begin{tabular}{|l|} 
Cross- \\
sectional \\
survey \\
with \\
intervie
\end{tabular} & $\begin{array}{l}\text { Delta region of } \\
\text { Nigeria } \\
41 \text { nursing students }\end{array}$ & $\begin{array}{l}\text { Sexual harassment } \\
\text { and related factors } \\
\text { (Researcher- } \\
\text { developed survey }\end{array}$ & $\begin{array}{l}\text { Feelings } \\
\text { Ways of coping } \\
\text { (Same survey }^{1} \text { ) }\end{array}$ & $\begin{array}{l}14.60 \% \text { strongly } \\
\text { agreed and } \\
9.80 \% \text { agreed in } \\
\text { response to the } \\
\text { question "Have }\end{array}$ & $\begin{array}{l}\text { Coping strategies: did nothing }(2.4 \%) \text {, were } \\
\text { shocked }(22.0 \%) \text {, ignored it }(9.8 \%) \text {, complained to } \\
\text { staff }(19.5 \%) \text {, left the scene }(31.7 \%) \text {, joked } \\
(2.4 \%), \text { and complained to family member or } \\
\text { friend }(51.2 \%) \text {. }\end{array}$ \\
\hline
\end{tabular}




\begin{tabular}{|c|c|c|c|c|c|c|c|}
\hline & Nigeria. & $\mathrm{w}$ & & and Interview) & & \begin{tabular}{|l|}
$\begin{array}{l}\text { you been a } \\
\text { victim of sexual } \\
\text { harassment?" }\end{array}$ \\
Sources of \\
sexual \\
harassment in \\
the last six \\
months: doctor \\
$(4.9 \%)$, lecturer \\
$(14.5 \%)$, co- \\
worker $(0.0 \%)$, \\
co-student \\
$(29.3 \%)$, patient \\
$(2.4 \%)$, \\
refused/missing \\
$(48.8 \%)$
\end{tabular} & $\begin{array}{l}\text { Feelings: anger (53.7\%), frustration (12.2\%), fear } \\
(17.1 \%) \text {, helpless (7.3\%), depressed (24.4\%), and } \\
\text { humiliation }(17.1 \%) \text {. }\end{array}$ \\
\hline $\begin{array}{l}\text { Takaki, } \\
\text { Taniguchi, \& } \\
\text { Hirokawa } \\
(2013)\end{array}$ & $\begin{array}{l}\text { Investigate } \\
\text { associations of } \\
\text { workplace bullying } \\
\text { and harassment with } \\
\text { headache, stiffness } \\
\text { of the neck or } \\
\text { shoulders, lumbago, } \\
\text { and pain of two or } \\
\text { more joints. }\end{array}$ & \begin{tabular}{|l|} 
Cross- \\
sectional \\
survey
\end{tabular} & $\begin{array}{l}35 \text { healthcare or } \\
\text { welfare facilities in } \\
\text { Japan } \\
1,642 \text { workers } \\
\text { (professional } \\
\text { caregivers, nurses, } \\
\text { clerks, } \\
\text { nutritionists, and } \\
\text { others) }\end{array}$ & $\begin{array}{l}\text { Sexual harassment } \\
\text { in the context of } \\
\text { employment } \\
\\
\text { (Negative Acts } \\
\text { Questionnaire, } \\
\text { (Einarsen \& } \\
\text { Raknes, 1997) }\end{array}$ & $\begin{array}{l}\text { Frequency of pain } \\
\text { in last month } \\
\text { Four-point scale } \\
\text { developed by } \\
\text { researchers }\end{array}$ & \begin{tabular}{|l|} 
Mean sexual \\
harassment score \\
on scale of 3 to \\
$15: 3.38$ for men \\
and 3.25 for \\
women
\end{tabular} & $\begin{array}{l}\text { Headache, stiffness of neck and shoulders, } \\
\text { lumbago, and pain of two or more joints were } \\
\text { significantly positively associated with sexual } \\
\text { harassment in women [prevalence ratio }(\mathrm{PR}) \text { at } \\
95 \% \text { confidence interval }(\mathrm{CI})=1.08,1.03,1.05, \\
1.09 \text { respectively]. } \\
\\
\text { Lumbago and pain of two or more joints were } \\
\text { significantly positively associated with sexual } \\
\text { harassment in men [PR at } 95 \% \mathrm{CI}=1.07 \text { and } 1.13 \\
\text { respectively]. }\end{array}$ \\
\hline $\begin{array}{l}\text { Kvas, \& Seljak } \\
(2014)\end{array}$ & $\begin{array}{l}\text { Explore violence in } \\
\text { nursing as } \\
\text { experienced by } \\
\text { nurses in Slovenia. }\end{array}$ & \begin{tabular}{|l|} 
Cross- \\
sectional \\
survey
\end{tabular} & $\begin{array}{l}\text { National Register } \\
\text { of qualified nurses } \\
\text { and midwives in } \\
\text { Slovenia } \\
692 \text { nurses }\end{array}$ & \begin{tabular}{|l|} 
Experiences of \\
sexual violence: \\
unwanted sexual \\
advances in verbal, \\
non-verbal or \\
physical form that \\
injures a person's \\
dignity, such as \\
unnecessary \\
touching, fondling, \\
sexual innuendo, \\
sending email with \\
sexual content, \\
suggestive remarks \\
and comments, \\
sexually insinuating \\
comments or
\end{tabular} & $\begin{array}{l}\left.\begin{array}{l}\text { Actions following } \\
\text { violent acts } \\
\text { Reasons for inaction } \\
(\text { Same survey }\end{array}{ }^{1}\right) \\
\end{array}$ & $\begin{array}{l}11.4 \% \text { of } \\
\text { participants had } \\
\text { experienced } \\
\text { sexual violence } \\
\text { in the past year. }\end{array}$ & $\begin{array}{l}\text { Actions following sexual violence: formal written } \\
\text { report }(8.7 \%) \text {; oral report/discussion with a } \\
\text { superior (24.3\%); notified the professional } \\
\text { association/union }(8.7 \%) \text {; discussed it with co- } \\
\text { workers/colleague }(40.5 \%) \text {; did nothing/discussed } \\
\text { it with nobody }(17.9 \%) \text {. } \\
\text { Reasons why participants did not report acts of } \\
\text { sexual violence: because nothing would change or } \\
\text { because of prior negative experience (51.7\%); fear } \\
\text { of losing one's job (25.0\%); fear of the person } \\
\text { initiating violence }(15.0 \%) \text {; belief that the victim } \\
\text { caused the violence }(1.7 \%) \text {; other }(6.7 \%) \text {. }\end{array}$ \\
\hline
\end{tabular}




\begin{tabular}{|c|c|c|c|c|c|c|c|}
\hline & & & & \begin{tabular}{|l|} 
gestures, sexist \\
jokes, forced sexual \\
intercourse, \\
attempted rape or \\
rape \\
(Workplace \\
Violence in \\
Nursing, researcher- \\
developed survey) \\
\end{tabular} & & & \\
\hline $\begin{array}{l}\text { Gleberzon, } \\
\text { Statz, \& Pym } \\
\text { (2015) }\end{array}$ & $\begin{array}{l}\text { To survey a group of } \\
\text { female chiropractors } \\
\text { and inquire as to } \\
\text { whether or not they } \\
\text { have been sexually } \\
\text { harassed by their } \\
\text { patients. }\end{array}$ & \begin{tabular}{|l|} 
Cross- \\
sectional \\
survey
\end{tabular} & $\begin{array}{l}\text { The Canadian } \\
\text { Memorial } \\
\text { Chiropractic } \\
\text { College (CMCC) } \\
19 \text { female faculty } \\
\text { members }\end{array}$ & $\begin{array}{l}\text { Experience of } \\
\text { sexual harassment } \\
\text { while in a clinical } \\
\text { setting: suggestive } \\
\text { looks; sexual } \\
\text { remarks; suggestive } \\
\text { physical gestures; } \\
\text { receiving } \\
\text { inappropriate gifts; } \\
\text { pressure for } \\
\text { romantic dates; } \\
\text { exposure of body } \\
\text { part in a sexually } \\
\text { suggestive way; } \\
\text { inappropriate } \\
\text { brushing, touching, } \\
\text { or grabbing; } \\
\text { unwanted contact; } \\
\text { unwanted } \\
\text { communication; and } \\
\text { other compliments } \\
\text { on make-up/hair } \\
\text { (Modeled on survey } \\
\text { used by Phillips \& } \\
\text { Schneider, 1993) }\end{array}$ & $\begin{array}{l}\text { Response to } \\
\text { harassment } \\
\left(\text { Same survey }{ }^{1}\right)\end{array}$ & $\begin{array}{l}11 \text { participants } \\
\text { experienced } \\
\text { sexual } \\
\text { harassment } \\
\text { while in a } \\
\text { clinical setting. } \\
\text { Sources: } 8 \text { were } \\
\text { harassed by } \\
\text { patients and } 3 \text { by } \\
\text { other } \\
\text { chiropractors or } \\
\text { office staff. }\end{array}$ & $\begin{array}{l}\text { Number of participants who responded to the } \\
\text { harassment in the following ways: ignored or } \\
\text { continued care (3); gave a verbal warning (3); } \\
\text { immediate dismissal (0); delayed dismissal after } \\
\text { attempted continued care (1); legal action (0); and } \\
\text { contacted malpractice carrier (0). }\end{array}$ \\
\hline $\begin{array}{l}\text { Boafo, } \\
\text { Hancock, \& } \\
\text { Gringart } \\
(2016)\end{array}$ & $\begin{array}{l}\text { To document the } \\
\text { incidence, sources, } \\
\text { and effects of } \\
\text { workplace verbal } \\
\text { abuse and sexual } \\
\text { harassment against } \\
\text { Ghanaian nurses. }\end{array}$ & \begin{tabular}{|l|} 
Cross- \\
sectional \\
study
\end{tabular} & $\begin{array}{l}12 \text { public hospitals } \\
\text { in five regions of } \\
\text { Ghana ( } 2 \text { teaching } \\
5 \text { regional, } 5 \\
\text { district hospitals) } \\
\\
592 \text { professional } \\
\text { nurses }\end{array}$ & \begin{tabular}{|l|} 
Sexual harassment \\
Adapted from \\
International Labour \\
Organisation, \\
International \\
Council of Nurses, \\
the World Health \\
Organization, and \\
the Public Services \\
\end{tabular} & $\begin{array}{l}\text { Reactions to sexual } \\
\text { harassment } \\
\left(\text { same survey }^{1}\right)\end{array}$ & $\begin{array}{l}12.2 \% \text { of } \\
\text { participants } \\
\text { exposed sexual } \\
\text { harassment in } \\
\text { the past } 12 \\
\text { months. } \\
\text { Perpetrators: } \\
\text { patient }(11.3 \%) \\
\text { patient's }\end{array}$ & $\begin{array}{l}\text { Reponses to sexual harassment: took no action } \\
\text { (23.6\%); told the person to stop (55.6\%); told } \\
\text { family/friends }(8.3 \%) \text {; told a colleague (40.3\%); } \\
\text { sought transfer to another unit }(1.4 \%) ; \text { completed } \\
\text { an incident form (1.4\%); sought help form } \\
\text { association }(11.1 \%) ; \text { tried to pretend it never } \\
\text { happened }(11.1 \%) \text {; tried to defend myself } \\
\text { physically }(47.2 \%) ; \text { sought counseling }(1.4 \%) ; \\
\text { reported to a senior staff/in-charge (4.2\%); } \\
\text { pursued prosecution (1.4\%); took action to }\end{array}$ \\
\hline
\end{tabular}




\begin{tabular}{|c|c|c|c|c|c|c|}
\hline & & & & $\begin{array}{l}\text { International health } \\
\text { sector workplace } \\
\text { violence } \\
\text { questionnaire (ILO } \\
\text { et al., 2003). }\end{array}$ & $\begin{array}{l}\text { relations } \\
(18.3 \%), \text { doctor } \\
(54.9 \%), \text { nurse } \\
(7.0 \%), \text { other } \\
\text { staff }(8.5 \%) .\end{array}$ & $\begin{array}{l}\text { investigate the incident (4.2\%). } \\
\text { Reason for not reporting incidents of sexual } \\
\text { harassment: it was not important }(80.6 \%) \text {; such } \\
\text { abuse is part of the job (11.3\%); I felt ashamed } \\
\text { (22.6\%); I was afraid of negative consequences } \\
\text { (3.2\%); no action will be taken if reported } \\
\text { (19.4\%); did not know to whom to report (53.2\%); } \\
\text { other reasons (9.7\%). } \\
\text { Effects: repeated disturbing memories (33.8\%); } \\
\text { avoided thinking or talking about the incident or } \\
\text { having feeling related to it (46.4\%); and being } \\
\text { "super alert" or watchful and on guard }(66.2 \%) \text {. }\end{array}$ \\
\hline $\begin{array}{l}\text { Nielson, Kjær, } \\
\text { Aldrich, } \\
\text { Madsen, } \\
\text { Friborg, } \\
\text { Rugulies, \& } \\
\text { Folker (2017) }\end{array}$ & $\begin{array}{l}\text { Investigate the } \\
\text { experience and } \\
\text { handling of sexual } \\
\text { harassment from } \\
\text { patients in care } \\
\text { work. }\end{array}$ & $\begin{array}{l}\text { Explorat } \\
\text { ory } \\
\text { qualitati } \\
\text { ve }\end{array}$ & $\begin{array}{l}\text { Hospital } \\
\text { emergency } \\
\text { department (1), } \\
\text { hospital neurology } \\
\text { department (1), } \\
\text { nursing home (2), } \\
\text { psychiatric } \\
\text { residential facility } \\
\text { (4), community } \\
\text { health and } \\
\text { rehabilitation } \\
\text { center (1), } \\
\text { residential care } \\
\text { facility for patients } \\
\text { with traumatic } \\
\text { brain injury (1) in } \\
\text { Denmark. } \\
\\
39 \text { care workers; } \\
38 \text { female, } 1 \text { male; } \\
1 \text { managers, } 6 \text { shop } \\
\text { stewards, } 3 \text { safety } \\
\text { representatives, } \\
\text { and } 19 \text { employees. } \\
\text { Included } 13 \text { trained } \\
\text { nurses, } 11 \\
\text { eldercare workers, } \\
9 \text { pedagogues } \\
\text { (teachers), } 5 \\
\text { physio- and ergo } \\
\text { therapist, and } 1 \\
\text { medical doctor. }\end{array}$ & & & $\begin{array}{l}\text { Sexual harassment is a complex and multifaceted } \\
\text { phenomenon. Themes and subthemes include the } \\
\text { following: } \\
\text { (1) Ambiguity in meaning and language: (a) a } \\
\text { multifaceted phenomenon, (b) unclear } \\
\text { terminology, (c) blurred lines } \\
\text { (2) Care workers reactions and responses: (a) } \\
\text { emotional reactions including fear, shock, } \\
\text { insecurity, powerlessness, shame, and self-blame; } \\
\text { (b) normalization; (c) withdrawal, avoidance, and } \\
\text { disclosure; (d) standing up for oneself } \\
\text { (3) Organizational measures and workplace } \\
\text { culture: (a) attitudes toward sexual harassment; (b) } \\
\text { guidelines and policies; (c) support and shielding; } \\
\text { and (d) ensuring that patients sexual needs are met }\end{array}$ \\
\hline
\end{tabular}




\begin{tabular}{|c|c|c|c|c|c|c|c|}
\hline $\begin{array}{l}\text { Yang, Stone, } \\
\text { Perini, \& } \\
\text { Morris (2018) }\end{array}$ & $\begin{array}{l}\text { Investigate the } \\
\text { incidence, type, } \\
\text { related factors, and } \\
\text { effects of workplace } \\
\text { violence on mental } \\
\text { health nurses as well } \\
\text { as identifying coping } \\
\text { strategies }\end{array}$ & \begin{tabular}{|l|} 
cross- \\
sectional \\
survey
\end{tabular} & $\begin{array}{l}\text { Mental health } \\
\text { hospital in Wuhan, } \\
\text { China } \\
290 \text { Chinese nurses }\end{array}$ & $\begin{array}{l}\text { Sexual harassment: } \\
\text { verbal sexual } \\
\text { harassment, sexual } \\
\text { harassment with } \\
\text { bodily touch } \\
\text { (Researcher- } \\
\text { developed } \\
\text { questionnaire) }\end{array}$ & $\begin{array}{l}\text { Burnout: emotional } \\
\text { exhaustion, } \\
\text { depersonalization, } \\
\text { reduced personal } \\
\text { accomplishment } \\
\\
\text { (The Maslach } \\
\text { Burnout Inventory - } \\
\text { General Survey, } \\
\text { Schutte, Toppinen, } \\
\text { Kalimo, \& } \\
\text { Schaufeli, 2000) }\end{array}$ & \begin{tabular}{|l} 
Percentage of \\
participants who \\
had at least one \\
incident of \\
sexual \\
harassment \\
$(63.4 \%)$, verbal \\
sexual \\
harassment \\
$(53.4 \%)$, and \\
sexual \\
harassment with \\
bodily touch \\
$(42.9 \%)$. \\
Incidence of \\
sexual \\
harassment by \\
perpetrator: \\
patients $(\mathrm{M}=$ \\
$1.24, \mathrm{SD}=$ \\
$1.34)$, visitors \\
$(\mathrm{M}=1.7, \mathrm{SD}=$ \\
$0.29)$, not \\
indicated $\mathrm{M}=$ \\
$1.08, \mathrm{SD}=$ \\
$1.02)$.
\end{tabular} & 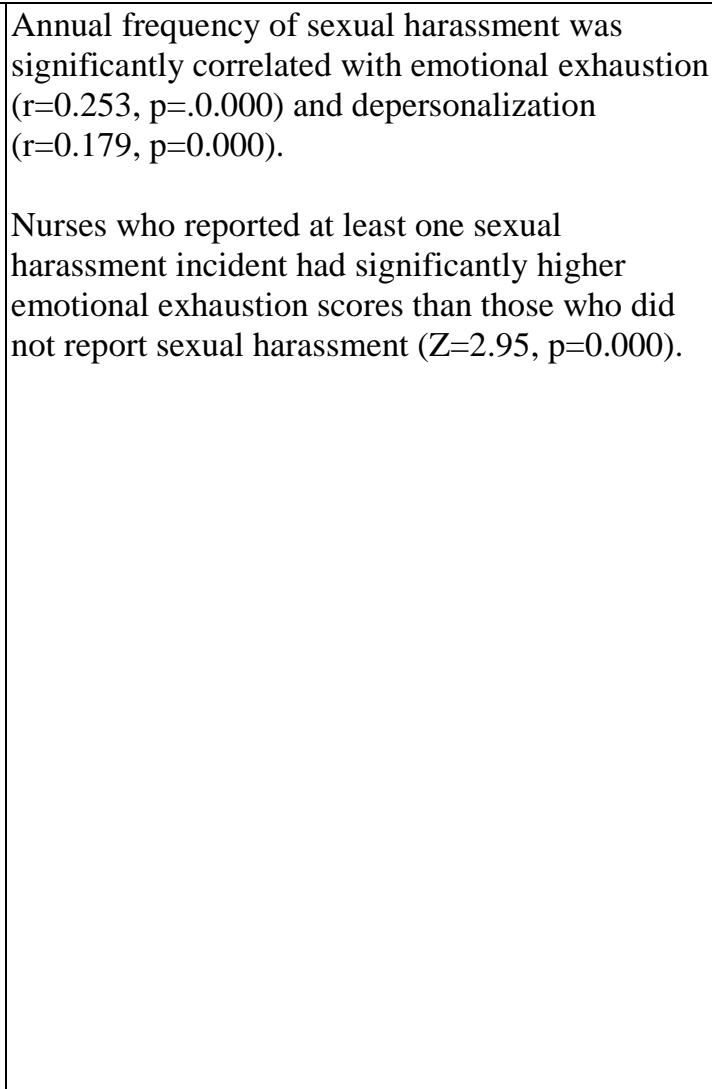 \\
\hline
\end{tabular}


Table 2. Characteristics of the Reports

\begin{tabular}{|c|c|}
\hline Country & \\
\hline Turkey $(\mathrm{n}=3)$ & $\begin{array}{l}\text { Çelik \& Çelik, } 2007 \\
\text { Talas et al., } 2011 \\
\text { Ulusoy et al., } 2011\end{array}$ \\
\hline South Africa $(n=1)$ & Levin \& Traub, 2006 \\
\hline New Zealand $(\mathrm{n}=1)$ & Wilkinson et al., 2006 \\
\hline United States $(\mathrm{n}=1)$ & MacKusick \& Minick, 2010 \\
\hline Taiwan $(\mathrm{n}=1)$ & Pai \& Lee, 2011 \\
\hline Australia $(\mathrm{n}=1)$ & Demir \& Rodwell, 2012 \\
\hline Nigeria $(\mathrm{n}=1)$ & Johnson, 2013 \\
\hline $\operatorname{Japan}(\mathrm{n}=1)$ & Takaki et al., 2013 \\
\hline Slovenia $(\mathrm{n}=1)$ & Kvas \& Seljak, 2014 \\
\hline Canada $(\mathrm{n}=1)$ & Gleberzon et al., 2015 \\
\hline Ghana $(\mathrm{n}=1)$ & Boafo et al., 2016 \\
\hline Denmark $(\mathrm{n}=1)$ & Nielson et al., 2017 \\
\hline China $(n=1)$ & Yang et al., 2018 \\
\hline Study Designs & \\
\hline Cross-sectional survey $(\mathrm{n}=13)$ & $\begin{array}{l}\text { Levin \& Traub, 2006 } \\
\text { Wilkinson et al., } 2006 \\
\text { Çelik \& Çelik, } 2007 \\
\text { Talas et al., 2011 } \\
\text { Ulusoy et al., } 2011 \\
\text { Pai \& Lee, 2011 } \\
\text { Demir \& Rodwell, } 2012 \\
\text { Johnson, 2013 } \\
\text { Takaki et al., 2013 } \\
\text { Kvas \& Seljak, 2014 } \\
\text { Gleberzon, et al., } 2015 \\
\text { Boafo et al., } 2016 \\
\text { Yang et al. 2018 }\end{array}$ \\
\hline Qualitative $(\mathrm{n}=2)$ & $\begin{array}{l}\text { MacKusick \& Minick, } 2010 \\
\text { Nielson et al., } 2017\end{array}$ \\
\hline Samples & \\
\hline Nursing and/or nursing students $(\mathrm{n}=8)$ & $\begin{array}{l}\text { Çelik \& Çelik, } 2007 \\
\text { MacKusick \& Minick, } 2010 \\
\text { Pai \& Lee, 2011 } \\
\text { Demir \& Rodwell, } 2012 \\
\text { Johnson, 2013 } \\
\text { Kvas, \& Seljak, } 2014 \\
\text { Boafo et al., } 2016 \\
\text { Yang et al., 2018 } \\
\end{array}$ \\
\hline $\begin{array}{l}\text { Healthcare workers of several disciplines (n } \\
=3 \text { ) }\end{array}$ & $\begin{array}{l}\text { Talas et al., 2011 } \\
\text { Takaki et al., } 2013 \\
\text { Nielson et al., } 2017 \\
\end{array}$ \\
\hline
\end{tabular}




\begin{tabular}{|l|l|}
\hline Medical students $(\mathrm{n}=2)$ & $\begin{array}{l}\text { Wilkinson et al., 2006 } \\
\text { Ulusoy et al., 2011 }\end{array}$ \\
\hline $\begin{array}{l}\text { Qualified speech language pathologists and } \\
\text { audiologists (SLP/As) and SLP/A students ( } \\
=1)\end{array}$ & Levin \& Traub, 2006 \\
\hline Faculty of chiropractic medicine $(\mathrm{n}=1)$ & Gleberzon et al., 2015 \\
\hline
\end{tabular}


Table 3. Harassment-related Feelings Reported by Over 20\% of Sample Who Experienced Sexual Harassment

\begin{tabular}{|l|c|c|c|c|}
\hline & $\begin{array}{c}\text { Levin \& Traub } \\
(2006)\end{array}$ & $\begin{array}{c}\text { Çelik \& Çelik } \\
(2007)\end{array}$ & $\begin{array}{c}\text { Talas et al. } \\
(2011)\end{array}$ & $\begin{array}{c}\text { Johnson } \\
(2013)\end{array}$ \\
\hline $\begin{array}{l}\text { Feeling } \\
\text { uncomfortable }\end{array}$ & $22.6^{1}$ & & & \\
\hline Anger & & $69.7 \%$ & $81.4 \%$ & $53.7 \%$ \\
\hline Fear & & $23.4 \%$ & $51.7 \%$ & \\
\hline Disappointment & & & $74.4 \%$ & \\
\hline Sadness & & & $86.0 \%$ & \\
\hline Powerlessness & & & $39.5 \%$ & \\
\hline Low self-esteem & & & $23.2 \%$ & \\
\hline Anxiety & & & $58.1 \%$ & \\
\hline Fury/Hate & & & $72.0 \%$ & \\
\hline Animosity & & & $41.8 \%$ & \\
\hline Helplessness & & & $44.2 \%$ & \\
\hline Despair & & & $37.2 \%$ & \\
\hline Failure & & & $37.2 \%$ & \\
\hline $\begin{array}{l}\text { Shock/ } \\
\text { Astonishment }\end{array}$ & & & $23.8 \%$ & $22.0 \%$ \\
\hline Feel lowly & & & $20.9 \%$ & \\
\hline Guilt/shame & & & $62.8 \%$ & \\
\hline Disgust & & & & $24.4 \%$ \\
\hline Depression & & & & \\
\hline${ }^{\text {sstudents only }}$ & & & & \\
\hline
\end{tabular}

